\title{
Densification and mechanical behavior of $\beta$-tricalcium phosphate bioceramics
}

\author{
Behzad Mehdikhani $^{1,2, *}$, Gholam Hossein Borhani ${ }^{2}$ \\ ${ }^{1}$ Construction and Mining Department, Standard Research Institute, Karaj, Iran \\ ${ }^{2}$ Department of Materials Engineering, Malek-e-ashtar University of Technology, Isfahan, Iran \\ *E-mail address: mehdikhani@standard.ac.ir
}

\begin{abstract}
Nano-size $\beta$-tricalcium phosphate powders with average grain size of $80 \mathrm{~nm}$ were prepared by the wet chemical precipitation method with calcium nitrate and di-ammonium hydrogen phosphate as calcium and phosphorus precursors, respectively. The precipitation process employed was also found to be suitable for the production of sub-micrometre $\beta$-TCP powder in situ. The sinterability of the nano-size powders, and the microstructure, mechanical strength of the prepared $\beta$-TCP bioceramics were investigated. Bioceramic sample characterization was achieved by powder X-ray diffraction (XRD), scanning electron microscopy (SEM), fourier transform infrared spectroscopy (FTIR), and density measurements. Powders compacted and sintered at 800, 900, 1000 and $1100{ }^{\circ} \mathrm{C}$ showed an increase in relative density from $70 \%$ to $93 \%$. The results revealed that the maximum hardness of 240 $\mathrm{H}_{\mathrm{V}}$ was obtained for $\beta$-TCP sintered at $1100^{\circ} \mathrm{C}$.
\end{abstract}

Keywords: Beta tricalcium phosphate, Bioceramic, Sintering, Mechanical properties

\section{INTRODUCTION}

Calcium phosphate bioceramics are materials of choice for bone tissue repair because of their similarity of composition with bone mineral; excellent bioactivity; ability to promote cellular expressions; and osteoconductivity [1-3]. The calcination constitutes a necessary step of the preparation when wet chemical routes are used for the synthesis of calcium phosphate, i.e. precipitation from the neutralization of $\mathrm{Ca}(\mathrm{OH})_{2}$ with $\mathrm{H}_{3} \mathrm{PO}_{4}$ or from the decomposition of $\mathrm{Ca}\left(\mathrm{NO}_{3}\right)_{2}$ and $\left(\mathrm{NH}_{4}\right)_{2} \mathrm{HPO}_{4}$. Moreover, the analysis of particle growth during calcination is required for the understanding of grain growth phenomena that occur during the final stages of the densification [4]. $\beta$-TCP ceramic is known as $\beta$-whitlockite and is a slowdegrading resorbable phase [5] and is thus a promising material in biomedical applications. $\beta$-TCP is known to have significant biological affinity and activity, and hence responds well to the physiological environments [6]. Because of these positive characteristics, porous $\beta$-TCP is regarded as an ideal bone substitute, which would degrade in vivo with time allowing bone tissue to grow inside the scaffold [7].

TCP has three polymorphs, such as: $\beta$-TCP is stable below $1180{ }^{\circ} \mathrm{C}, \alpha$-TCP between $1180{ }^{\circ} \mathrm{C}$ and $1400{ }^{\circ} \mathrm{C}$, and $\alpha$-TCP above $1470{ }^{\circ} \mathrm{C}$. Among the three allotropic forms, $\beta$-TCP is preferredas a bioceramic on account of its chemical stability, mechanical strength, and proper bioresorption rate. To use $\beta$-TCP ceramics as surgical implants, the mechanical strength of $\beta$ - 
TCP ceramics must be as high as possible. So it is important to density $\beta$-TCP ceramics intensively.

Generally, it is difficult to sinter $\beta$-TCP ceramics fully because $\beta$-TCP ceramics should be sintered at lower temperature than that of phase transition to $\alpha-\mathrm{TCP}[8]$. TCP is a resorbable temporary bone space filler material. When implanted, TCP will interact with body fluids and form HA in accordance to the following equation:

$$
4 \mathrm{Ca}_{3}\left(\mathrm{PO}_{4}\right)_{2}+2 \mathrm{H}_{2} \mathrm{O} \rightarrow \mathrm{Ca}_{10}\left(\mathrm{PO}_{4}\right)_{6}(\mathrm{OH})_{2}(\text { surface })+\mathrm{Ca}_{2}+2 \mathrm{HPO}_{4}{ }^{2-}
$$

The reaction rate will decrease with increasing $\mathrm{pH}$ of the local solution and further increases the solubility of TCP. Theoretically, resorbable TCP is an ideal implant material. After implantation, TCP will degrade with time and be replaced with natural tissues. It leads to the regeneration of tissues instead of their replacement and so solves the problem of interfacial stability $[9,10]$. $\beta$-TCP powders are reportedly prepared by liquid-solution methods, such as sol-gel, hydrothermal, micro emulsion and precipitation, as well as gas phase reactions [11-13].

$\beta$-TCP is routinely used as bone replacement, especially in the field of oral and craniofacial surgery, in the form of granules and rods [14,15] or as filler in polymeric scaffolds [16]. In bulk, $\beta$-TCP bioceramics have mechanical properties too poor to be used in load-bearing clinical applications [17-19], which has been attributed to the difficulties in fully densifying $\beta$-TCP powders [18,20-22].

These difficulties are associated with the presumption that the sintering temperature should be kept below $1125^{\circ} \mathrm{C}$ to avoid the $\beta-\alpha$ phase transformation that is considered deleterious to mechanical properties. Material properties deemed particularly important when designing calcium phosphates with improved resorption are surface characteristics, such as: roughness, grain size and porosity, and chemical properties, in particular phase composition. It is possible to use different sintering regimes to change surface roughness, grain size and density for example by using high and low temperatures [23], however the use of high sintering temperatures causes unwanted phase changes to occur (e.g. $\beta$-TCP to $\alpha$-TCP) [24].

One of the critical controlling parameter that requires attention during the processing of $\beta$-TCP is the selection of a suitable sintering method to obtain a solid, high density $\beta$-TCP body that is characterized by having fine-grained microstructure [25]. Dense nanostructured bioceramic materials are usually obtained by pressing and conventional sintering of nanopowders using pressure assisted methods, such as hot pressing, hot isostatic pressing, sinter forging, etc. [26-28].

The high sintering temperatures and long sintering times required for the consolidation of $\beta$-TCP powders often result in extreme grain coarsening and decomposition of the $\beta$-TCP, which is characteristic for conventional sintering methods and results in the deterioration of the mechanical properties of $\beta$-TCP ceramics $[29,30]$.

The aim of this study was to determine the effects of sintering temperature on the microstructure and mechanical properties of $\beta$-TCP scaffolds by means of nanoindentation testing. In this study, $\beta$-TCP scaffolds were manufactured through wet chemical precipitation process and subsequently sintered at six different temperatures. $\beta$-TCP was characterized in terms of their crystallographic phases, microstructural morphology, grain size, density and hardness. 


\section{EXPERIMENTAL PROCEDURE}

\section{1. Powder synthesis}

The precipitation procedures that are used in the synthesis of $\beta$-TCP pure bioceramic powders are described in detail in the process flowcharts given in Figure 1. $\beta$-TCP nanopowders were synthesized by the reaction of calcium nitrate tetra-hydrate $\left(\mathrm{Ca}\left(\mathrm{NO}_{3}\right)_{2} \times 4 \mathrm{H}_{2} \mathrm{O}, 98 \%\right.$, Merck $)$ with diammonium hydrogen phosphate $\left(\left(\mathrm{NH}_{4}\right)_{2} \mathrm{HPO}_{4}, 99 \%\right.$, Merck). Briefly, $500 \mathrm{~mL}$ of $0.4 \mathrm{~mol}\left(\mathrm{NH}_{4}\right)_{2} \mathrm{HPO}_{4}$ solution with $\mathrm{pH}=4$ was vigorously stirred at room temperature, and $500 \mathrm{~mL}$ of $0.6 \mathrm{~mol} \mathrm{Ca}\left(\mathrm{NO}_{3}\right)_{2}$ with $\mathrm{pH}=7.3$ was added drop wise over 150-200 min to produce a white precipitate. Throughout the mixing process the $\mathrm{pH}$ of the system was maintained at $\mathrm{pH}=8$ by adding of $0.1 \mathrm{M}$ sodium hydroxide $(\mathrm{NaOH}, 99 \%$, Merck). The obtained white suspension was then stirred for $12 \mathrm{~h}$. The synthesized precipitate was washing with distilled water and then with $100 \%$ ethanol to improve the dispersion characteristics.

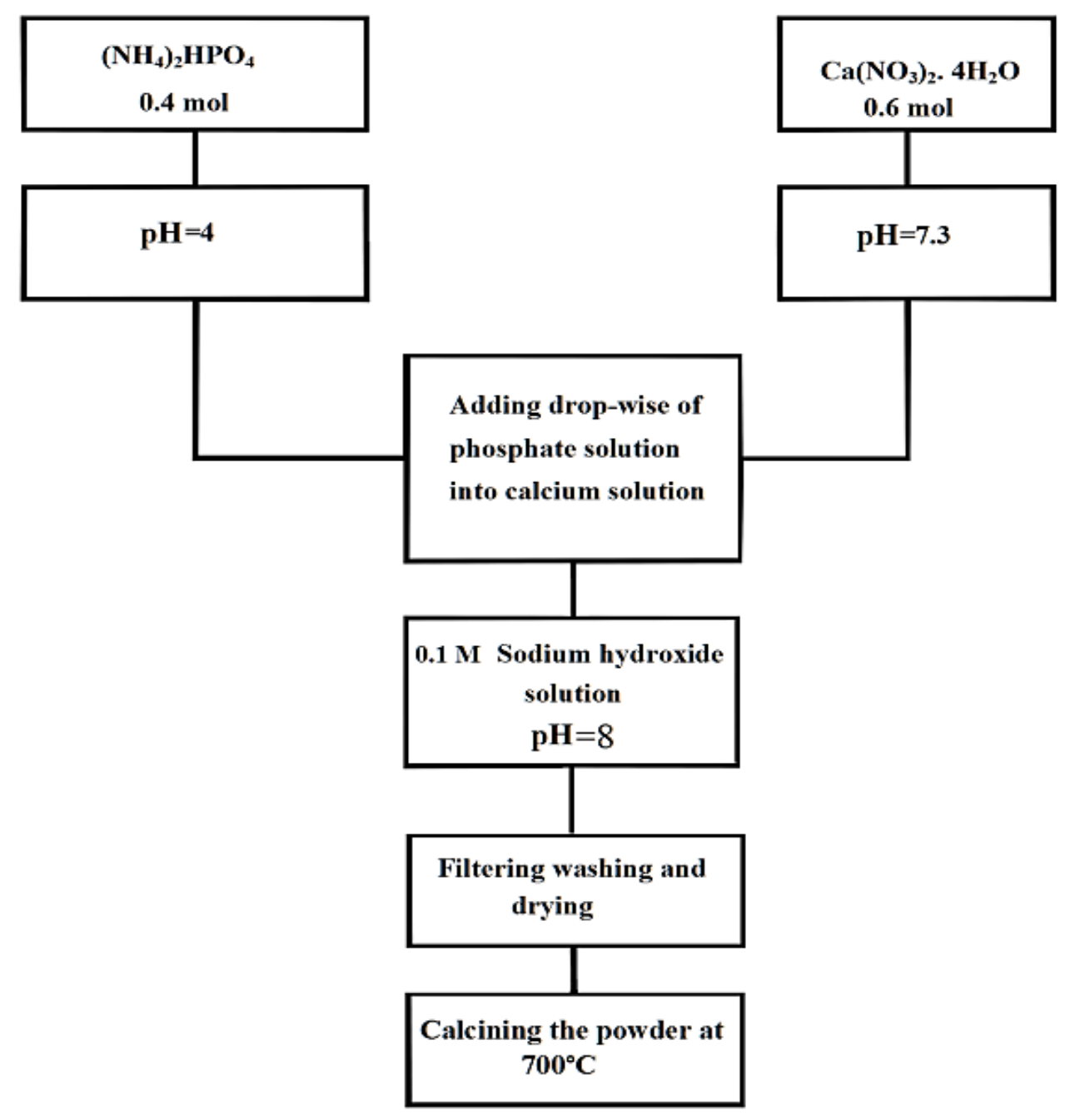

Figure 1. Chemical precipitation flowcharts used in the synthesis of $\beta$-TCP pure nano bioceramic powders. 
The suspension was filtered in a filter glass with application of mild suction. After filtration the compact, sticky filter cake, was dried at $80{ }^{\circ} \mathrm{C}$ for $24 \mathrm{~h}$. The as-dried powders were crushed by using mortar and pestle and calcined in alumina crucible at $700{ }^{\circ} \mathrm{C}$ for $2 \mathrm{~h}$.

The synthesized $\beta$-TCP powder was isostatically pressed at $50 \mathrm{MPa}$, for $1 \mathrm{~min}$, resulting into uniform green compacts, which were sintered at temperatures from $800{ }^{\circ} \mathrm{C}$ to $1100{ }^{\circ} \mathrm{C}$ in air atmosphere for $6 \mathrm{~h}$. The initial heating rate was $20{ }^{\circ} \mathrm{C} / \mathrm{min}$. $\beta$-TCP compact density was measured using Archimedes' method.

The sintered $\beta$-TCP compacts were tested for microhardness. Microhardness was measured with a Vicker's indenter. Samples were embedded in epoxy and surfaces were ground flat and polished to a $1 \mu \mathrm{m}$ finish with diamond paste. Each sample was indented 10 times with $200 \mathrm{~g}$ and $300 \mathrm{~g}$ loads. No effect of load on hardness values was noticed at these loads.

\section{2. Characterization of $\beta$-TCP Bioceramic Powders}

Evaluation of crystalline phases was investigated by X-ray diffractometer (Siemens, model D-500) using CuKa radiation. Silicon powder was used as the standard material for semi-quantitative analysis of precipitated phases. The mean crystallite size $(D)$ was calculated from the XRD line broadening measurement from the Scherrer equation [31]:

$$
D=0.89 \lambda / \beta \cos \theta
$$

where $\lambda$ is the wavelength of the used $\mathrm{Cu} \mathrm{K} \alpha$ radiation, $\beta$ is the full width at the half maximum of the $\beta$-TCP line and $\theta$ is the diffraction angle. Infrared spectra were performed by FTIR Bomem (model MB100, Quebec, Canada) in 400-4000 $\mathrm{cm}^{-1}$ wavenumber region.

For infrared spectroscopy, samples were pulverized and mixed with a given amount of potassium bromide $(\mathrm{KBr})$ and pressed in very thin tablets.

$\mathrm{The} \mathrm{Ca} / \mathrm{P}$ ratio of the dried powder was measured by inductively coupled plasma (ICP) atomic emission spectroscopy (model Varian). Powder morphology and particle size were evaluated using a scanning electron microscope (SEM, VEGA-TESCAN).

\section{RESULT AND DISCUSSION}

The morphologies of the TCP powder precipitated was shown in Figure 2. It can be seen that the $\beta$-TCP powder is highly agglomerated with almost spherical particles having average size of $70-100 \mathrm{~nm}$. The $\mathrm{Ca} / \mathrm{P}$ ratio of the $\beta$-TCP powder, as determined by ICP analyses, was $1.51 \pm 0.01$.

The XRD analysis was performed using the X-ray diffractometer. The straight base line and sharp peaks of the diffractogram in Figure 3 confirmed that the products were well crystallized. The results revealed that the as-prepared powder was composed of highly crystalline and no second phase other than b-TCP. The average crystallite size is determined by Scherrer equation, of this sample $80 \mathrm{~nm}$.

In order to identify the molecular arrangement of the precipitated powders, FT-IR analysis was performed. The FTIR spectrum of the powder prepared at $\mathrm{pH}=8$ is shown in Figure 4. The characteristic absorption bands at 3433 and $1631 \mathrm{~cm}^{-1}$ are attributed to adsorbed water. The bands at $900-1200 \mathrm{~cm}^{-1}$ were the stretching mode of $\mathrm{PO}_{4}{ }^{3-}$ group. The sharp peaks at 561 and $607 \mathrm{~cm}^{-1}$ represent the vibration peaks of $\mathrm{PO}_{4}{ }^{3-}$ in $\beta$-TCP [32-33]. 


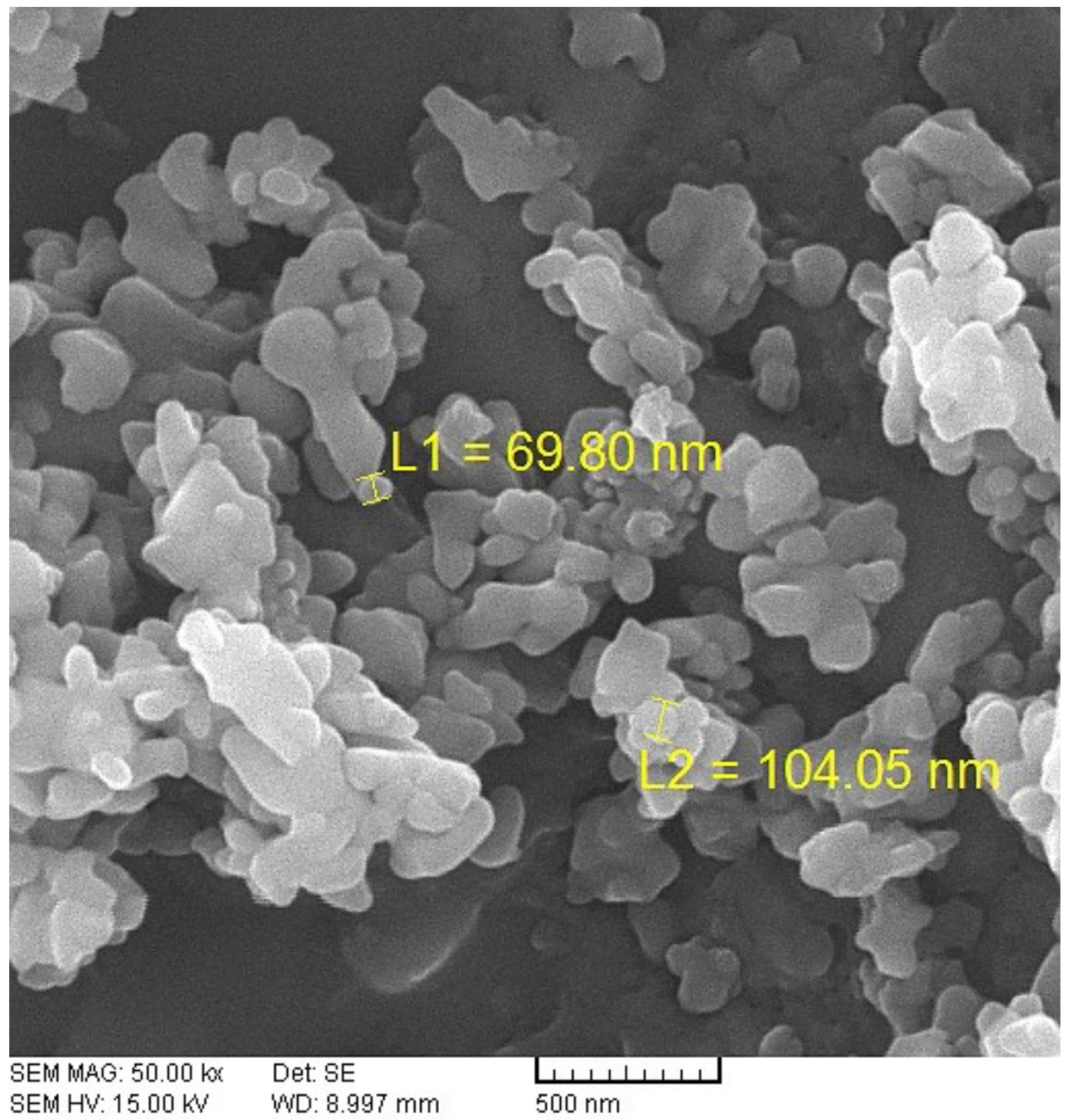

Figure 2. SEM photomicrographs of as-prepared $\beta$-TCP nanopowders.

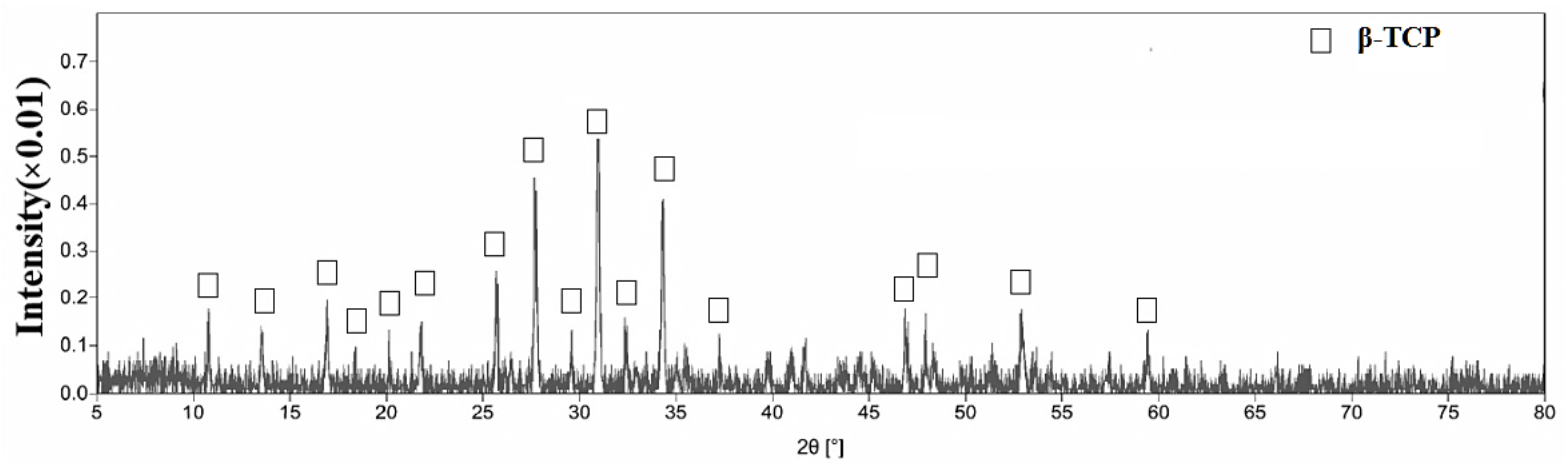

Figure 3. XRD patterns of $\beta$-TCP powders. 


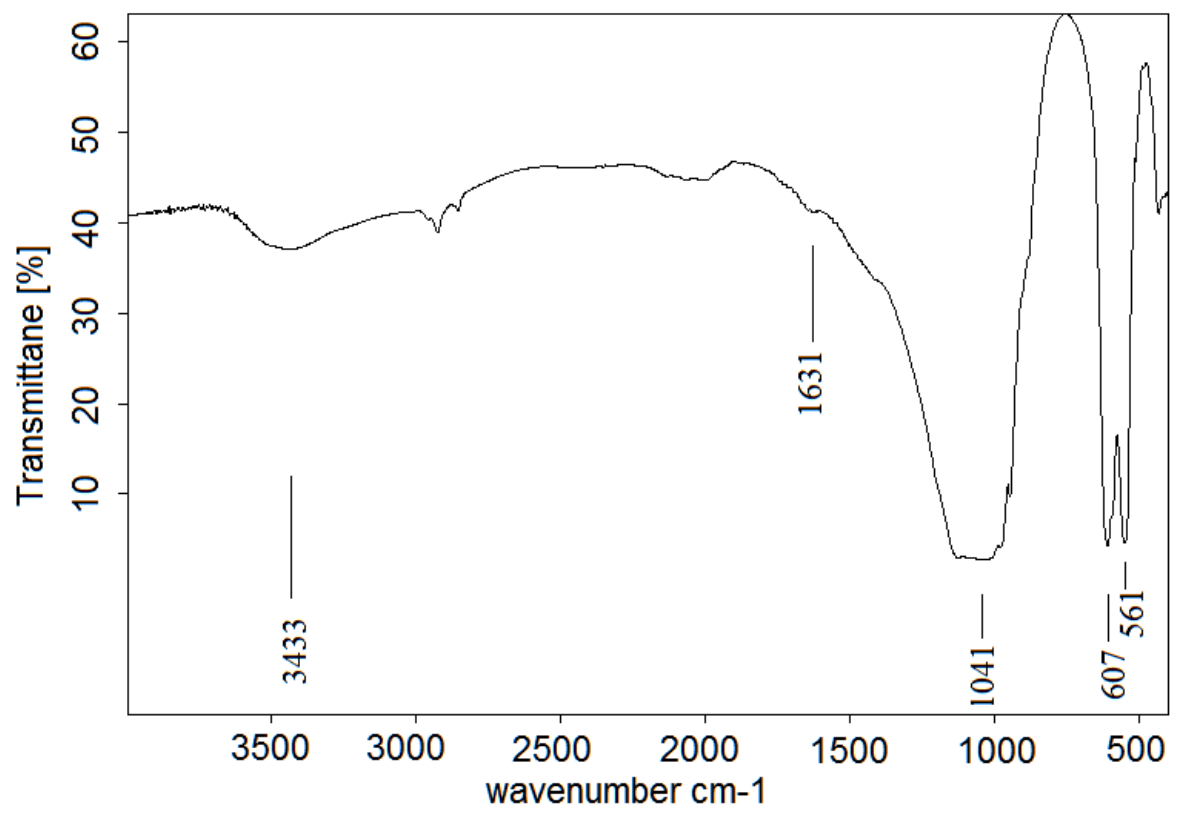

Figure 4. FTIR spectrum of $\beta$-TCP.

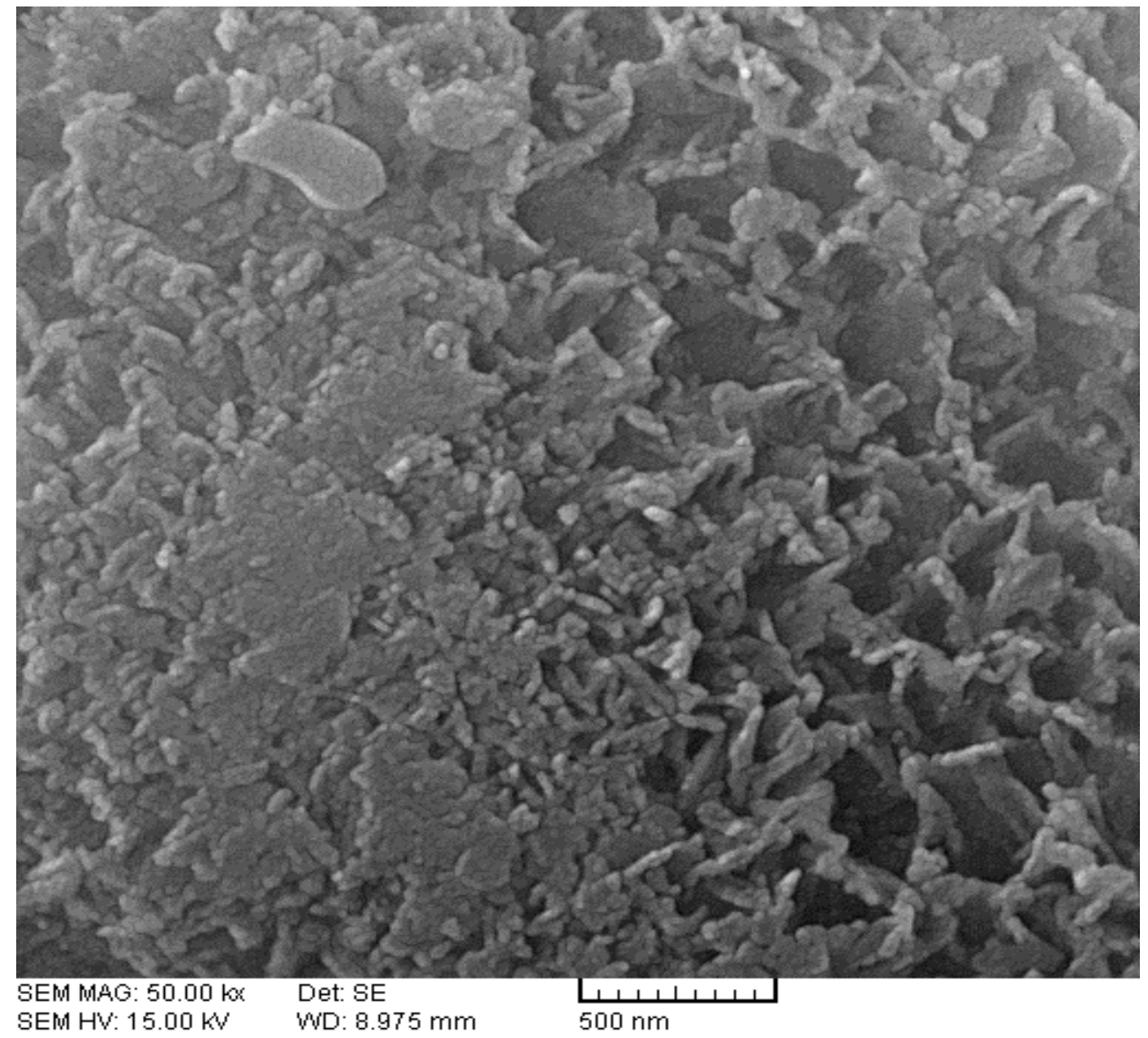

Figure 5. Typical SEM micrograph of a green compact of $\beta$-TCP powder pressed at $50 \mathrm{MPa}$. 
The SEM micrograph of the green compact isostatically pressed at $50 \mathrm{MPa}$ is shown in Figure 5. The compact, as can be clearly seen, was uniform, as the result of applied high isostatic pressure and the presence of soft aggregates in the starting $\beta$-TCP powder. The green compacts of $\beta$-TCP were sintered in air to obtain compacts having a dense microstructure. The green compact density was $1.36 \mathrm{~g} / \mathrm{cm}^{3}$, or $60.4 \%$ of the theoretical density. Figure 6 shows density of samples at different sintering temperatures. Density of samples increased up to $1100^{\circ} \mathrm{C}$.

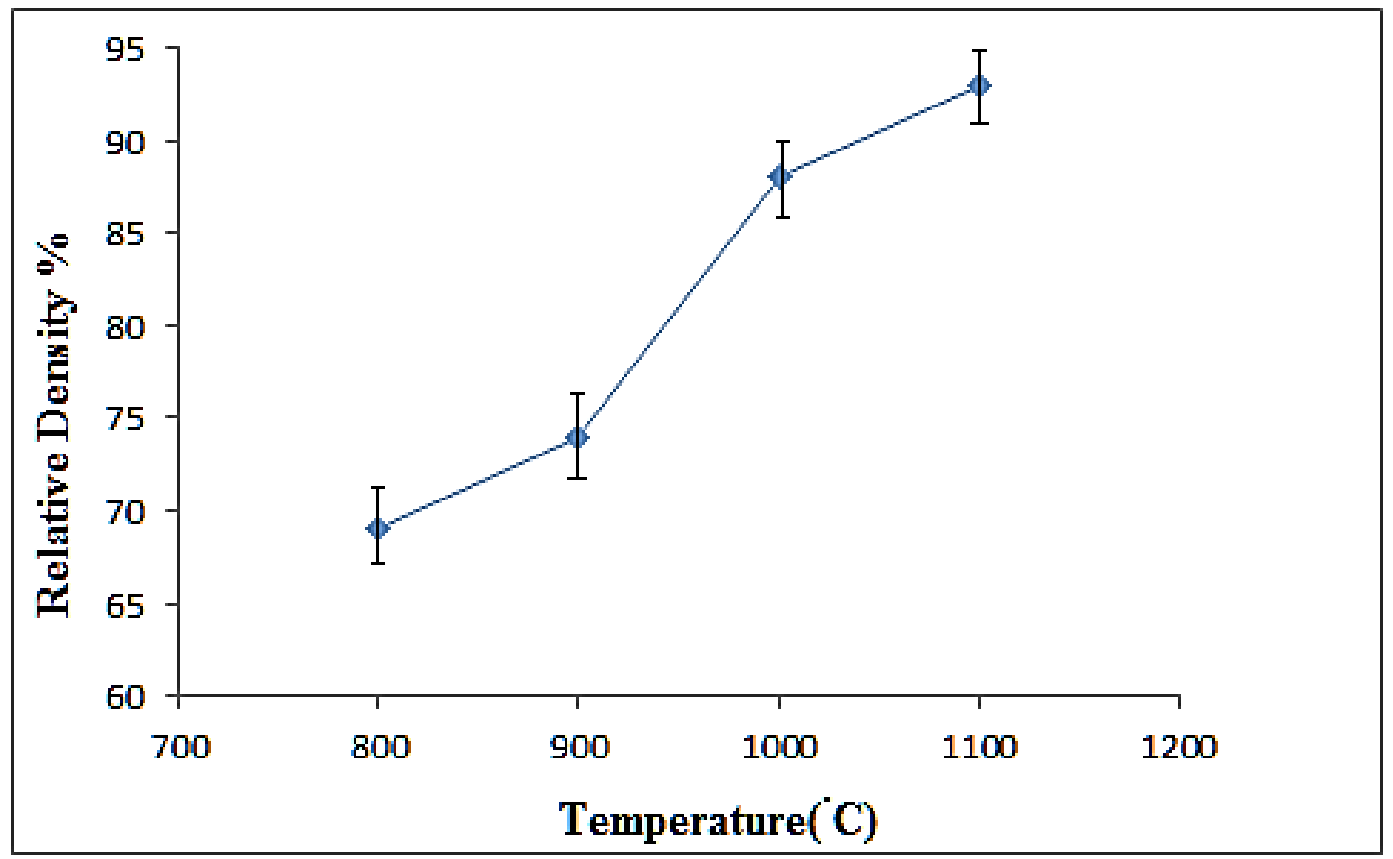

Figure 6. Relative density of $\beta$-TCP bioceramics fabricated from nano-size powders.

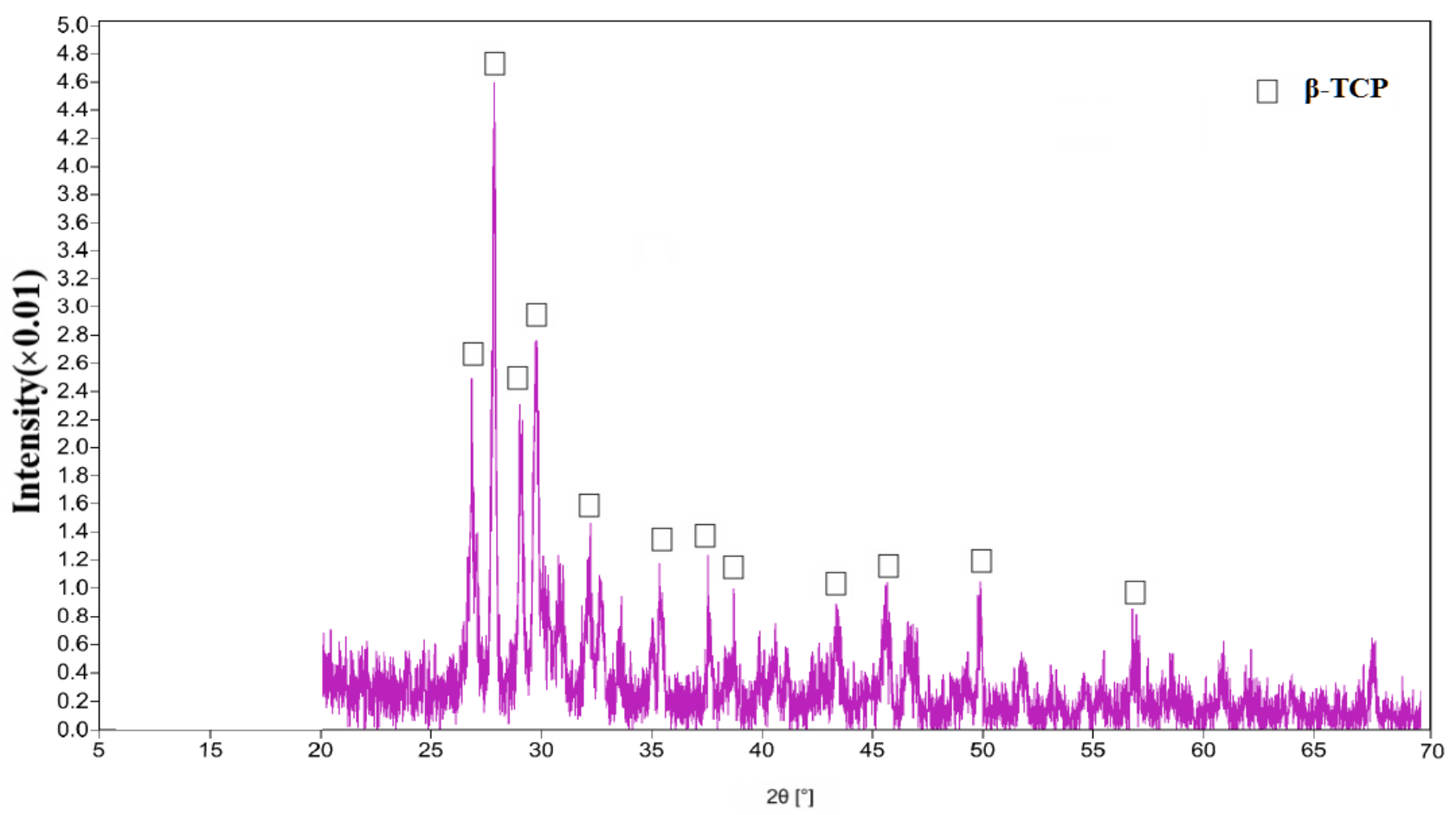

Figure 7. XRD patterns of $\beta$-TCP bioceramics prepared using nano-size powders: sintered at $1100{ }^{\circ} \mathrm{C}$. 
Hardness of samples increased by sintering temperature and reached to maximum at $1100{ }^{\circ} \mathrm{C}$. Figure 6 shows the relative densities (RD) of the samples sintered from nano-size powders as a function of the sintering temperature. Density could be seen to increase with increasing sintering temperature. When sintered at $800{ }^{\circ} \mathrm{C}$, the RD of the $\beta$-TCP powders only reached $68.29 \%$. With the increase of the sintering temperature to $1000{ }^{\circ} \mathrm{C}$, the relative density increased to $87.11 \%$. Further increase the temperatures, the RD increased sharply, and reached $93.66 \%$ at $1100{ }^{\circ} \mathrm{C}$. Figure 7 shows the XRD patterns of the sample sintered from the nano-size $\beta$-TCP powders. It can be seen that the sample sintered at $1100{ }^{\circ} \mathrm{C}$ was composed of highly crystalline and single-phase $\beta$-TCP, and no other phases were observed.

The SEM micrograph of the fracture surface of a samples obtained by sintering at 800 $1100{ }^{\circ} \mathrm{C}$ for $6 \mathrm{~h}$ are shown in Figure 8. Figure 8-a shows that spherical agglomerates of crystals approximately $100 \mathrm{~nm}$ in diameter. A fracture surface of sample fired at $900{ }^{\circ} \mathrm{C}$ is shown in Figure 8-b. The highly reactive spherical particles in the sample were joined by neck growth and a continuous pore channel was formed, as is clearly seen in the micrograph. The particles in the sample fired at $900{ }^{\circ} \mathrm{C}$ have lost their identity and considerable grain growth has occurred; the sample appears to be in the intermediate stage of sintering and the particles were approximately cylindrical with dimensions $1 \mu \mathrm{m} \times 0.25 \mu \mathrm{m}$. The fracture surface of a sample sintered at $1000{ }^{\circ} \mathrm{C}$, is shown in Figure 8-c. The grain boundaries and isolated pores are visible. The average grain size was $1.25 \mu \mathrm{m}$. Figure 8 -d shows the fracture surface of a sample sintered at $1100{ }^{\circ} \mathrm{C}$. Porosity was eliminated and the average grain size was $2.5 \mu \mathrm{m}$. During the intermediate and final stages of sintering, pore elimination has occurred without considerable grain growth. The linear shrinkage of the samples sintered at $800-1100{ }^{\circ} \mathrm{C}$ are shown in Figure 9. During the processing of sintering from $800{ }^{\circ} \mathrm{C}$ to $1100{ }^{\circ} \mathrm{C}$, linear shrinkage of the samples has increased.

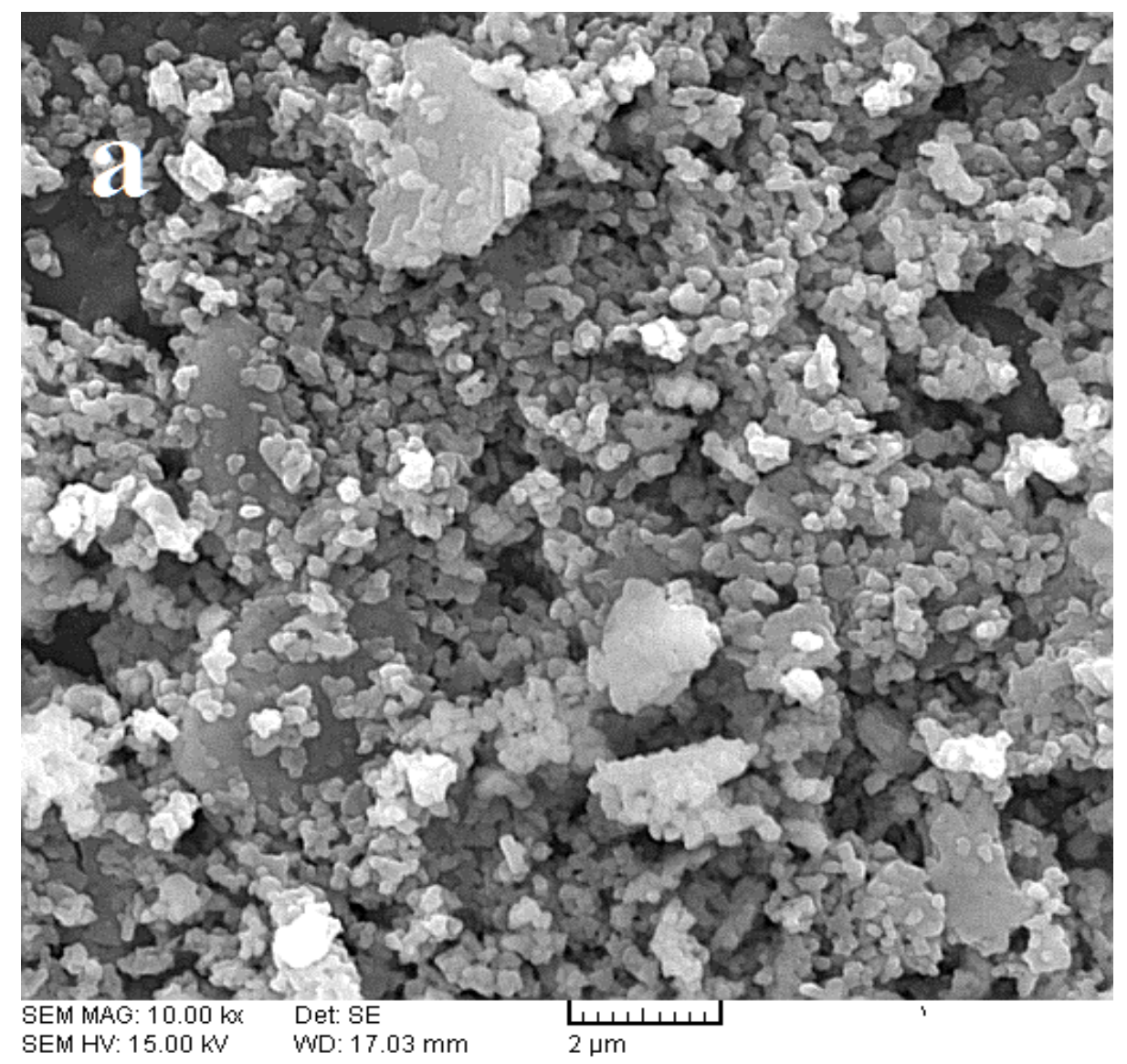



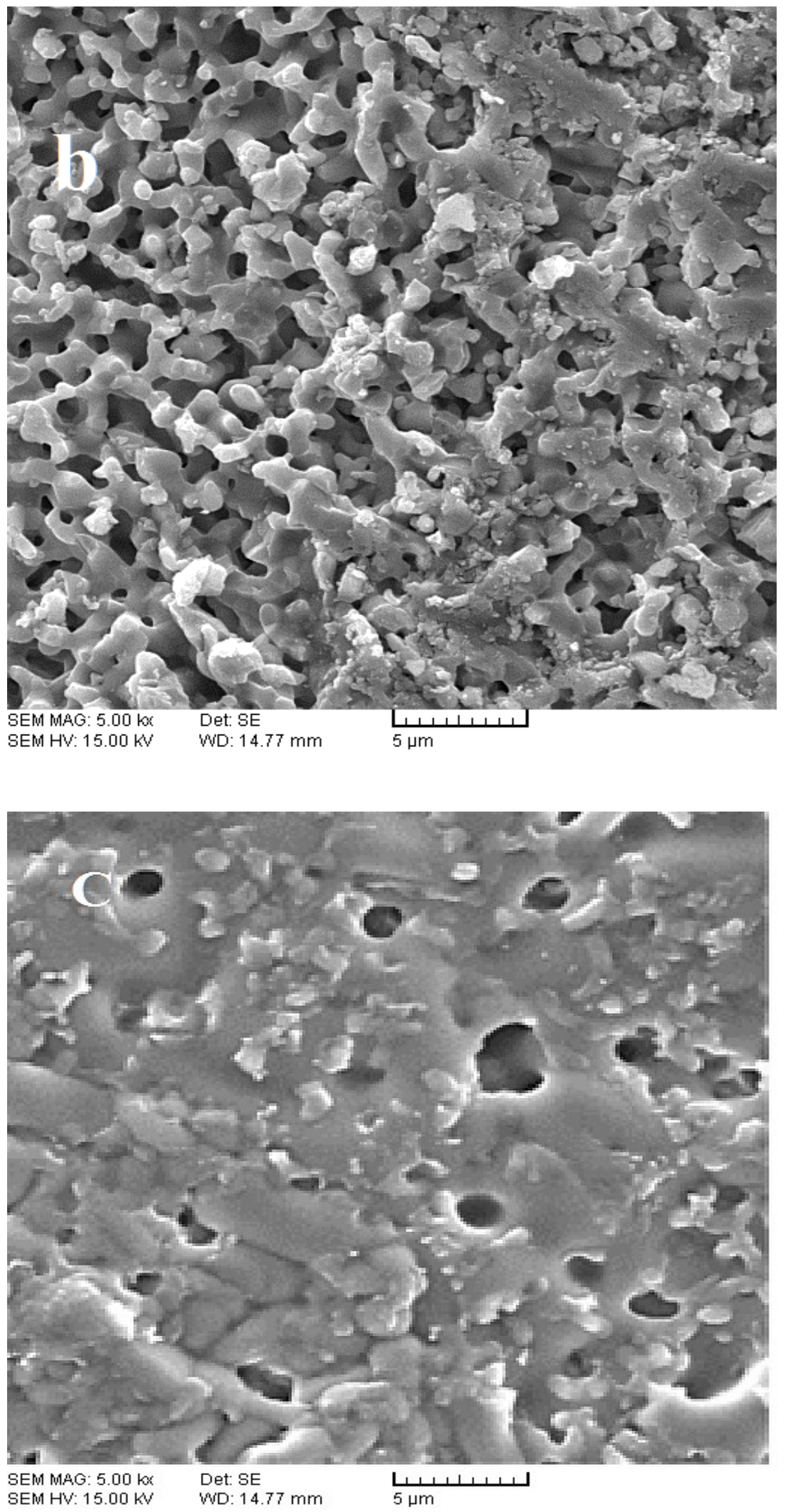


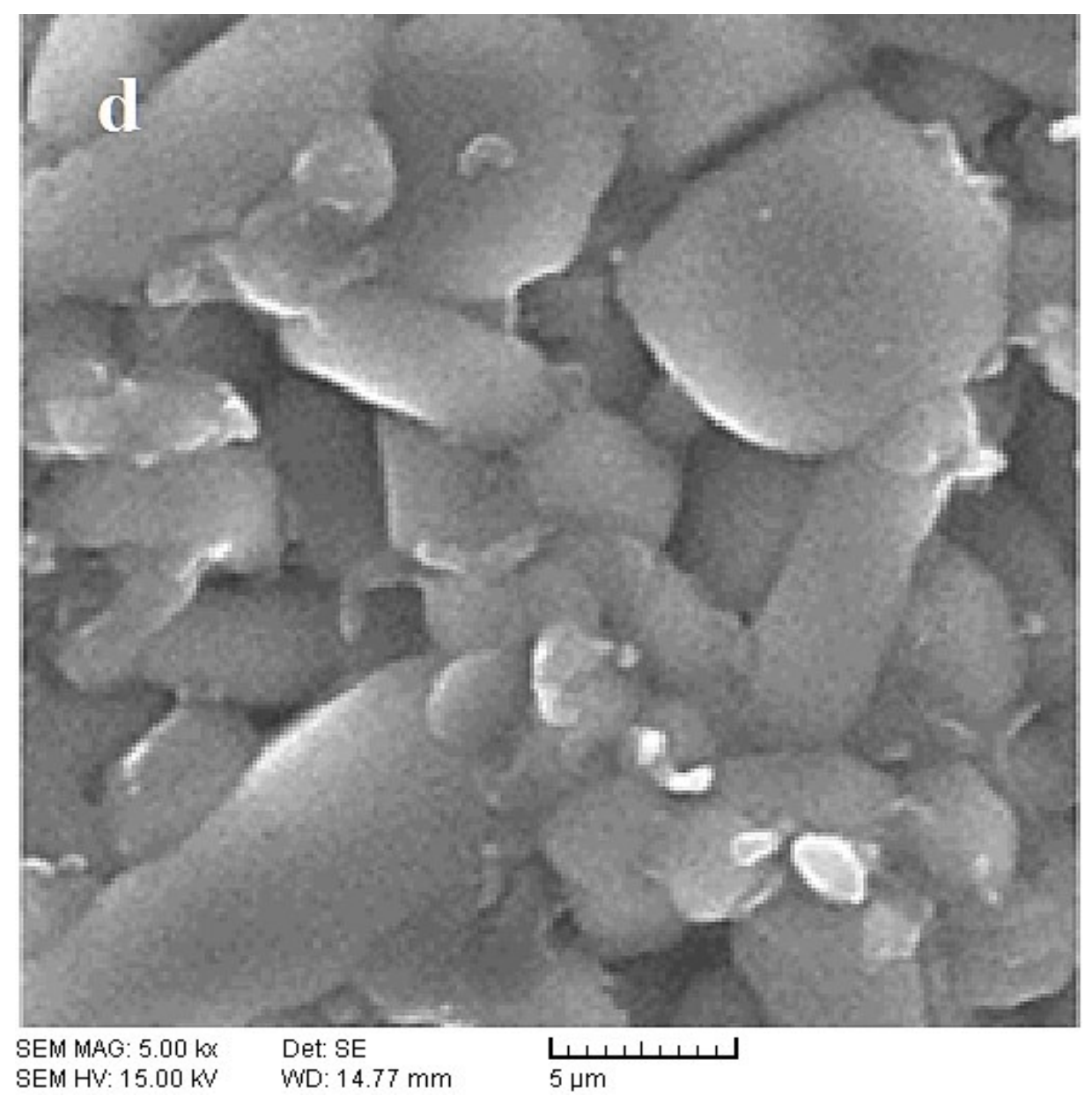

Figure 8. SEM micrographs of $\beta$-TCP powders sintered at various temperatures in air for $6 \mathrm{~h}$ after being uniaxially pressed at $50 \mathrm{MPa}$ : (a) $800^{\circ} \mathrm{C}$; (b) $900{ }^{\circ} \mathrm{C}$; (c) $1000{ }^{\circ} \mathrm{C}$; (d) $1100{ }^{\circ} \mathrm{C}$.

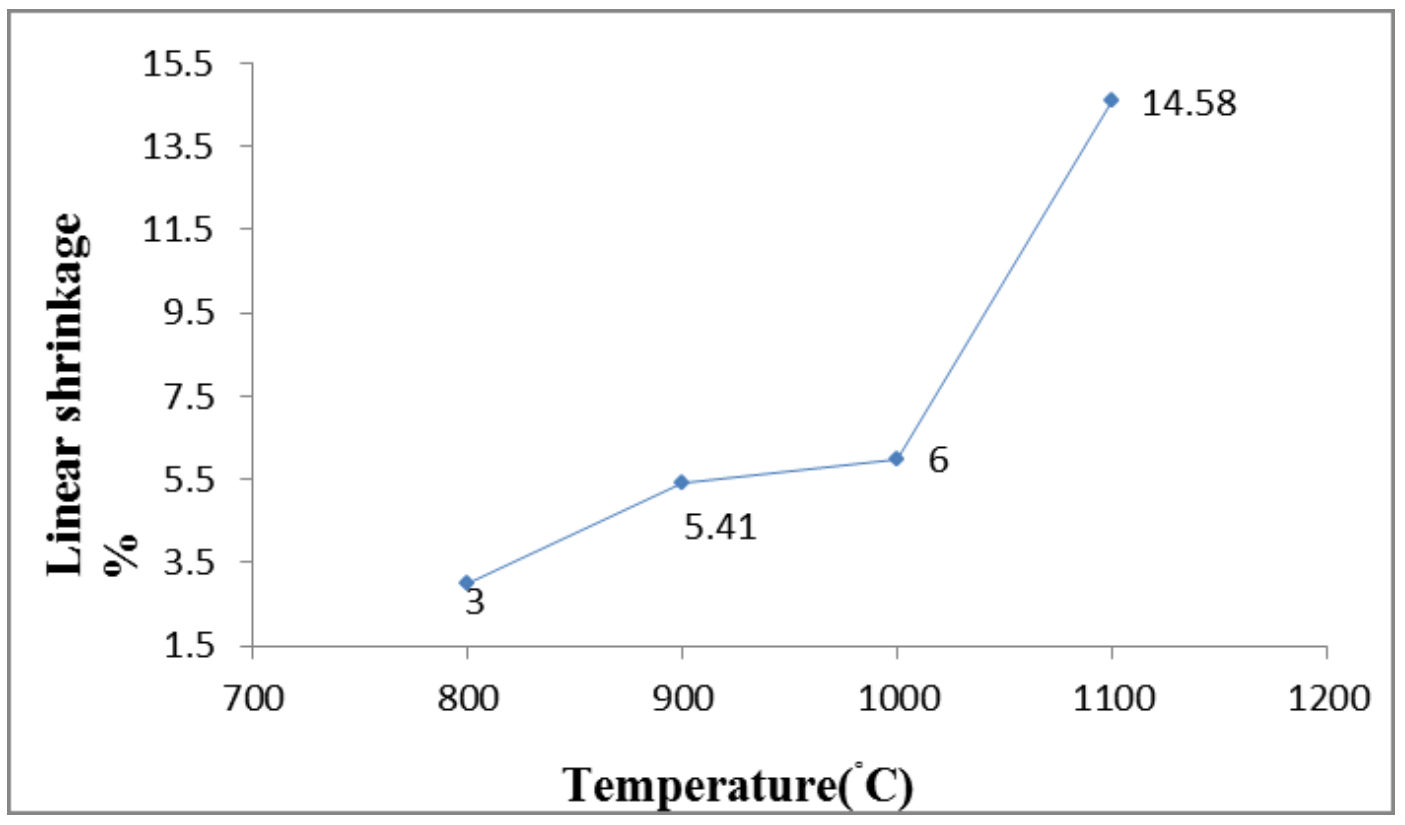

Figure 9. Linear shrinkage of $\beta$-TCP sintered at different temperatures. 
Figure 9 shows the linear shrinkage of $\beta$-TCP versus the temperature. With increasing of the temperature from $800{ }^{\circ} \mathrm{C}$ to $1000{ }^{\circ} \mathrm{C}$, the shrinkage of the samples insignificantly increased, but the shrinkage of sample rapidly increased, from $6.0 \%$ to $14.58 \%$ by sintering at $1100^{\circ} \mathrm{C}$.

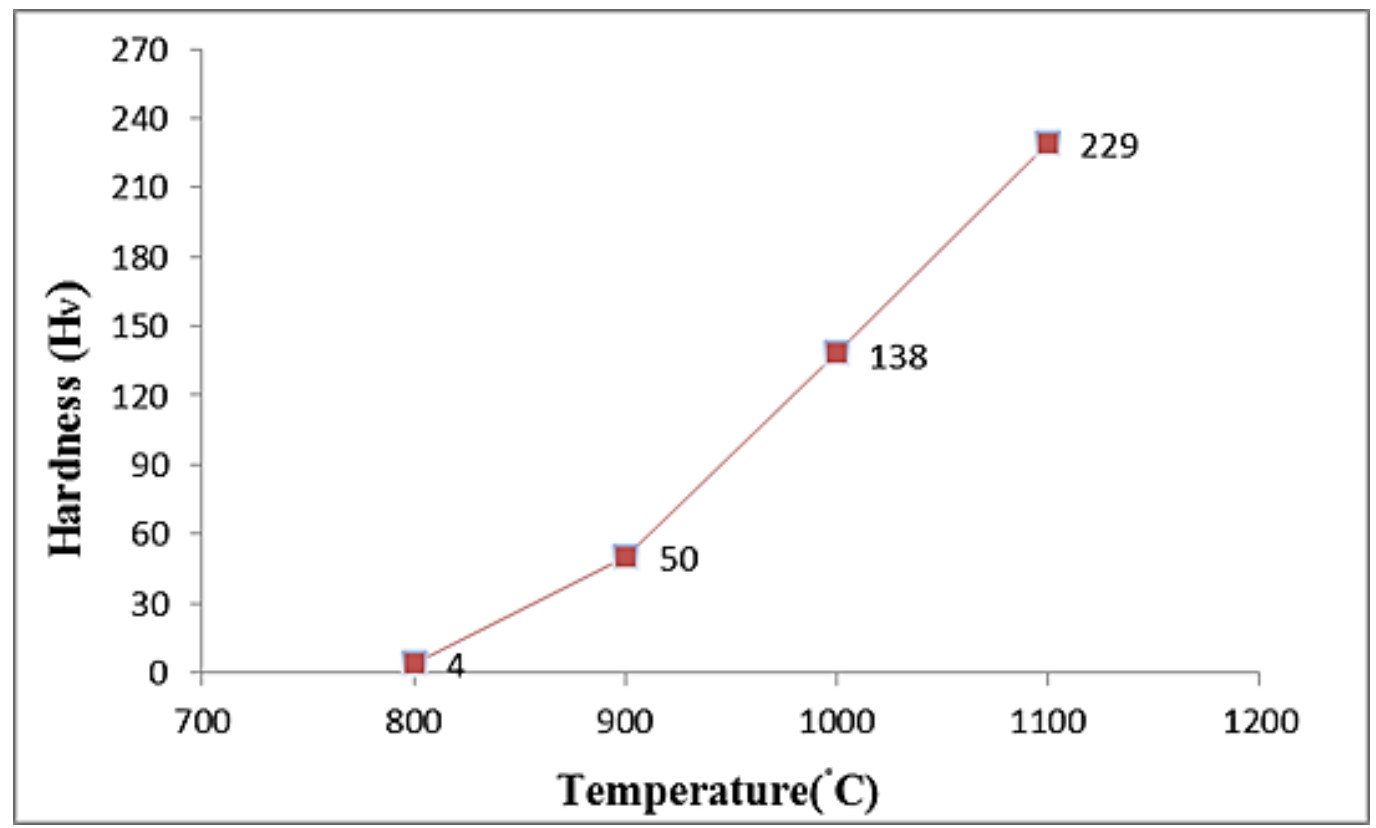

Figure 10. Vickers hardness of $\beta$-TCP sintered at various temperatures.

The effect of sintering temperature on the Vickers hardness of $\beta$-TCP sintered at various temperatures is shown in Figure 10. For the samples fabricated from nano-size $\beta$-TCP powders, an increase of the sintering temperature from $800{ }^{\circ} \mathrm{C}$ to $1100{ }^{\circ} \mathrm{C}$ resulted in the increase of the hardness, which was due to the improved density at higher sintering temperature.

\section{CONCLUSION}

In this study, the synthesis of biocompatible nano-sized $\beta$-TCP powder via wet precipitation method and using calcium and phosphorous precursors is reported. It is shown that high purity products, $\beta$-TCP nanopowder could be obtained by this simple process. The sample prepared at $\mathrm{pH}=8$ is $\beta$-TCP powder with $\mathrm{Ca} / \mathrm{P}$ ratio of 1.51 . The sintering ability of the nano-size $\beta$-TCP powders, and the microstructure and hardness of the prepared $\beta$-TCP bioceramics were investigated. Using nano-size $\beta$-TCP powders as raw materials is an effective way to obtain dense ceramics with high hardness at $1100{ }^{\circ} \mathrm{C}$ sintering temperature.

\section{Acknowledgement}

The authors are indebted to the Ceramic Laboratory (standard research Institute) that supplied the raw materials for development and financial support. 


\section{References}

[1] L.L. Hench, Bioceramics, J. Am. Ceram. Soc. 81 (1998).

[2] A. Ravaglioli, A. Krajewski, Bioceramics: Materials, Properties and Applications, Chapman and Hall, London, 1992.

[3] K.D. Groot, C.P.A.T. Klein, J.G.C. Wolke, J.M.A. Blieck-Hogervorst, Chemistry of Calcium Phosphate Bioceramics, in: T. Yamamuro, L.L. Hench, J. Wilson (Eds.), Handbook of Bioactive Ceramics, Vol. 2, Calcium Phosphate and Hydroxylapatite Ceramics, CRC Press, Boca Raton, FL, (1990), pp. 3-16.

[4] D. Bernache-Assollanta, A. Ababoua, E. Championa, M. Heughebaert, Journal of the European Ceramic Society 23 (2003) 229-241.

[5] F.C. Driessens, J.W. Van Dijk, J.M. Borggreven, Calcif. Tissue Res. 26 (1978) 127.

[6] N. Kivrak, A. C. Tas., J. Am. Ceram. Soc. 81 (1998) 2245-2252.

[7] M. Jarcho, R.L. Salsbury, M.B. Thomas, R.H. Doremus, J. Mater. Sci. 14 (1979) 142.

[8] B. Mirhadi, B, Mehdikhani, N. Askari, Processing and Application of Ceramics 5(4) (2011).

[9] K. de Groot, Ceram. Int. 19(5) (1993) 363-366.

[10] S. Metsger, T.D. Driskell, J.R. Paulsrud, J. Am. Dent. Assoc. 105 (1982) 1035-1038.

[11] K. Lin, J. Chang, J. Lu, W. Wu, Y. Zeng, Ceram. Int. 33 (2007) 979-985.

[12] J.S. Bow, S.C. Liou, S.Y. Chen, Biomater. 25 (2004) 3155-3161.

[13] F. Zhang, K. Lin, J. Chang, J. Lu, C. Ning, J. Eur. Ceram. Soc. 28 (2008) 539-545.

[14] H.H. Horch, R. Sader, C. Pautke, A. Neff, H. Deppe, A. Kolk, International Journal of Oral and Maxillofacial Surgery 35 (8) (2006) 708-713.

[15] U.W. Jung, H.I. Moon, C. Kim, Y.K. Lee, C.K. Kim, S.H. Choi, Current Applied Physics 5 (5) (2005) 507-511.

[16] M. Yoneda, H. Terai, Y. Imai, T. Okada, K. Nozaki, H. Inoue, S. Miyamoto, K. Takaoka, Biomaterials 26 (25) (2005) 5145-5152.

[17] M. Sous, R. Bareille, F. Rouais, D. Clement, J. Amedee, B. Dupuy, C. Baquey, Biomaterials 19 (23) (1998) 2147-2153.

[18] P. Miranda, E. Saiz, K. Gryn, A.P. Tomsia, Acta Biomaterialia 2(4) (2006) 457-466.

[19] P. Miranda, A. Pajares, E. Saiz, A.P. Tomsia, F. Guiberteau, Journal of Biomedical Materials Research Part A 85A (1) (2008) 218-227.

[20] H.S. Ryu, H.J. Youn, K.S. Hong, B.S. Chang, C.K. Lee, S.S. Chung, Biomaterials 23(3) (2002) 909-914.

[21] R. Famery, N. Richard, P. Boch, Ceramics International 20(5) (1994) 327-336.

[22] K. Itatani, T. Nishioka, S. Seike, F.S. Howell, A. Kishioka, M. Kinoshita, Journal of the American Ceramic Society 77 (3) (1994) 801-805.

[23] Rahaman M.N., Ceramic Processing. Boca Raton: Taylor \& Francis; 2007.

[24] Huang J., Pan Y., Shao C.Y., J Mater Sci. 28 (2003) 1049-1056. 
[25] S. Ramesh, C.Y. Tan, S.B. Bhaduri, W.D. Teng, I. Sopyan, Journal of materials processing technology 206 (2008) 221-230.

[26] M.J. Mayo, in: G.M. Chow, N.I. Noskova, Nanostructured (Eds.), Materials Science Technology, NATO ASI Series, Kluwer Academic Publishers, Russia, 1997, pp. 361-385.

[27] J.R. Groza, Nanosintering, Nanostruct. Mater. 12 (1999) 987-992.

[28] Dj. Veljovic, B. Jokic, I. Jankovic-Castvan, I. Smiciklas, R. Petrovic, Dj. Janackovic, Key Eng. Mater. 330-332 (2007) 259-262.

[29] Y.W. Gua, K.A. Khora, P. Cheang, Biomaterials 25 (2004) 4127-4134.

[30] C.Y. Tang, P.S. Uskokovic, C.P. Tsui, Dj. Veljovic, R. Petrovic, Dj. Janackovic, Ceram. Int. 35 (2009) 2171-2178.

[31] L.A. Azaroff, Elements of X-ray Crystallography, McGraw-Hill, New York, 1968, pp. 38-42.

[32] C. Biqin, Z. Zhaoquan, Z. Jingxian, L. Qingling, J. Dongliang, Mater. Sci. Eng. C, 28 (2008) 1052-1056.

[33] S. Raynaud, E. Champion, D. Bernache-Assollant, P. Thomas, Biomater. 23 (2002) 1065-1072. 